\title{
RISK OF DEVELOPMENT OF HYPERTENSION AFTER DONOR NEPHRECTOMY
}

\author{
Khurram Mansoor, Sohail Sabir, Sumbal Rana, Ali Arslan Munir, Muhammad Yasrab, Kaubaib Shahzad, Tanveer Sajid, \\ Syed Ehtesham Haider Naqvi \\ Armed Forces Institute of Urology/National University of Medical Sciences (NUMS) Rawalpindi Pakistan
}

\begin{abstract}
Objective: To assess live donor nephrectomy for development of hypertension.

Study Design: Retrospective observational study.

Place and Duration of Study: The study was conducted at Armed Forces Institute of Urology (AFIU) Rawalpindi, from May 2016 to May 2020.

Methodology: All consenting kidney donors for live renal transplant were introduced with the process. Baseline blood pressure at time of workup of donation and annually afterwards after transplant on follow up examinations using retrospective data analysis of donor's workup and follow up was used. Comparison of 1,2,3 and 4-year occurrence of hypertension among (normotensive) donors with 1,2,3 and 4-year of donation using estimates from Framingham Hypertension Risk Score.

Results: A total of 79 donors with a completed annual follow-up rate of up to100 \% during a 4-year period. The average age at donation was $33.96 \pm 10.23$ SD years; 50 donors (63.4\%) were women. Overall $27 \%$ (22 out of 79 ) of all live donors developed post donation hypertension who were normotensive at the time of donation. Almost 2/3rd of the patients developing hypertension were females. There was a significant increase in blood pressure measurements each year after donation. Increased BMI of the patient was a risk factor for post donation development of hypertension. The donors who continue being normotensive 1-year post donation yielded an analogous risk to that fit Framingham populace.

Conclusion: Live organ kidney givers are at augmented risk of development of hypertension post kidney donation. The study ascertains the potential significance of following donors and handling risk factors aggressively to avert hypertension and to increase donor survival.
\end{abstract}

Keywords: Consent, Framingham Score, Hypertension, Living kidney donor.

\footnotetext{
This is an Open Access article distributed under the terms of the Creative Commons Attribution License (http://creativecommons.org/licenses/by/4.0), which permits unrestricted use, distribution, and reproduction in any medium, provided the original work is properly cited.
}

\section{INTRODUCTION}

Living donor nephrectomy is increasing day by day as the candidates of kidney transplant are increasing enormously. Improved life probability and quality of life are significant benefits for recipients of live kidney donors as matched with dialysis or deceased donor transplantation ${ }^{1}$. The donor risks are usually lesser with some low postoperative deaths (nearly 3.1 deaths per 10000 procedures) $)^{2}$. This is very important to ascertain extended span health risks related with kidney donation. There is no certain data available to show if such donors develop hypertension or any other complication in the long run.

To date multiple studies have beenconducted internationally. Very minor augmented risk of developing hypertension or proteinuria over longstanding follow-up was detected in a meta-analysis of 48 studies which reported on outcome of 5145 donors as equated to age accorded controls. But contrary studies are also available showing development of hypertension and microalbuminuriain donors in long term ${ }^{3,4}$. In a study

Correspondence: Dr Sumbal Rana, Assistant Professor, Classified Anesthesiologist, AFIU Rawalpindi Pakistan

Received: 03 Jun 2020; revised received: 01 Dec 2020; accepted: 09 Dec 2020 conducted by Sanchez et al, their results establish that roughly as much as one third of population became hypertensive after donation and have almost alike chances to develop hypertension to what is seen in the general population ${ }^{5}$. They found that quarter of donors getting anti-hypertensive medications are poorly controlled (BP >140/90 $\mathrm{mmHg}$ ) and ten percent of donors without a diagnosis of hypertension had blood pressure readings falling in hypertensive range. A better understanding of metabolic outcomes is paramount in choosing the potential donors which can help in developing a long term guideline to retain good health status. None of such studies are conducted in Pakistan yet.

Development of a new, multicomponent score, grounded on Framingham data has allowed calculation of hypertension risk by making appropriate groups has circumvented problems associated with previous studies. This Framingham score is a gender based algorithm used to estimate the 10-year cardiovascular risk of an individual. It permits creating clusters comparable for age, gender, systolic and diastolic blood pressures, smoking habits and family history of hypertension. This score hasn't been included in statis- 
tical analysis in studies until a recent study conducted in Switzerland6.

Aim of this retrospective, long term study was to evaluate if nephrectomy is a risk factor for development of hypertension in kidney donors when compared with estimations of multivariate hypertension risk score of the Framingham cohort including pertinent risk considerations of hypertension for possible donors without nephrectomy.

\section{METHODOLOGY}

This retrospective observational study was conducted at Armed Forces Institute of Urology, from May 2016 to May 2020. It was a retrospective cohort study consisting of 79 donors. All participants who were registered for renal transplant donationwere well informed and written consent was taken for the use of data for clinical research purposes. Blood pressures were recorded before donation and followed yearly after donation. Hypertension was defined as systolic blood pressure $>140 \mathrm{mmHg}$ and/or diastolic $>90 \mathrm{~mm}$ $\mathrm{Hg}$, or use of any blood pressure-lowering medication. A mean of three separate measurements of blood pressure at each time taken before and yearly after donation during follow-up checkups was used for data report. Our inclusion criteria allowed only normotensive patients, all the patients who were hypertensive or were on antihypertensive medication were excluded. Newly identified cases of hypertension had to undergo $24 \mathrm{~h}$ ambulatory blood pressure recording for confirmation, using cutoff figure of $135 / 85 \mathrm{~mm} \mathrm{Hg}$ or higher. Only normal range blood pressure values were accepted as 'normal' if medicationsused the same day did exclude antihypertensive treatment. Only follow-up checkups with comprehensive data sets were analyzed. All this data was collected retrospectively by collecting information of consenting donors.

Variables which were interval-scaled were summarized with means and SDs or medians and IQRs, for statistical analysis, where appropriate. Dichotomous variates were labelled as ratios and percentages.

We used hypertension risk score of the Framingham cohort for 1, 2,3 \& 4-year risk of hypertension to our data to evaluate the outcome of donation on the manifestation of elevated blood pressure necessitating medication, as follows: for the initial year study we tailored the data to the dissemination prior to donation after discounting all cases of hypertension $(n=79)$. For the consequent 4-year analysis, we fixated on all donors lasting normotensive 1-year post donation.
Data documentation was also done for family history and smoking habits of the patients.

Comparison was made between the projected prospects from the Framingham calculations to the probabilities estimated from two multivariate logistic regression models, utilizing the manifestation of hypertension 1, 2, 3 \& 4-years after donation as the dependent variate and the existing parameters of the Framingham equation (age, female gender, blood pressure both systolic and diastolic, BMI, smoking status, family history of hypertension and acollaborationspan of age and diastolic blood pressure) pre-donation (for the 1year calculation) and at every 12 months after donation (for the 2, 3, 4-year assessment).

\section{RESULTS}

In the period of May 2016 to May 2020, all the patients included in the trial were contacted for retrospective examination of systolic and diastolic BP for assessment of development of hypertension after kidney donation. All of our population was local Pakistani community. Out of all the 79 patients 22 patients $(27 \%)$ developed hypertension which included 14 female patients $(17 \%)$ and 8 males $(10 \%)$.

Age wise group distribution has been shown in table-I. Age range pre-donation visit showed 34.77

Table-I: Comparison of age and BMI of two groups.

\begin{tabular}{l|c|c|c}
\hline & Normotensive & Hypertensive & $p$-value \\
\hline Age & $34.77 \pm 10.23$ & $33.96 \pm 7.67$ & $<0.001$ \\
\hline $\begin{array}{l}\text { Body Mass } \\
\text { Index }\end{array}$ & $22.95 \pm 3.18$ & $25.08 \pm 3.52$ & $<0.001$ \\
\hline
\end{tabular}

with standard deviation of 10.23 years in normotensive patients as compared to the patients who developed $33.96 \pm 7.67$ years. In BMI category, the normotensive donors had average pf $22.95 \pm 3.18$. As compared to hypertensive donors who were $25.08 \pm 3.52$ both groups had $p$-value of $<0.001$.

During the study the follow up of patients has been shown in figure. At the time of donation, all patients were evaluated and confirmed to be normotensive. The follow up of patients was phenomenal and up to $100 \%$, as only one donor from 2017 could not be followed up after two years of donation.

A detailed data of the patients developing hypertension with systolic and diastolic measurements have been tabulated in tables-II-VI. This data shows that the donors who were to develop hypertension, had normal blood pressure even after one year of donation. They start to develop the hypertension from the second year after donation onwards, as can be seen in the table-II to 


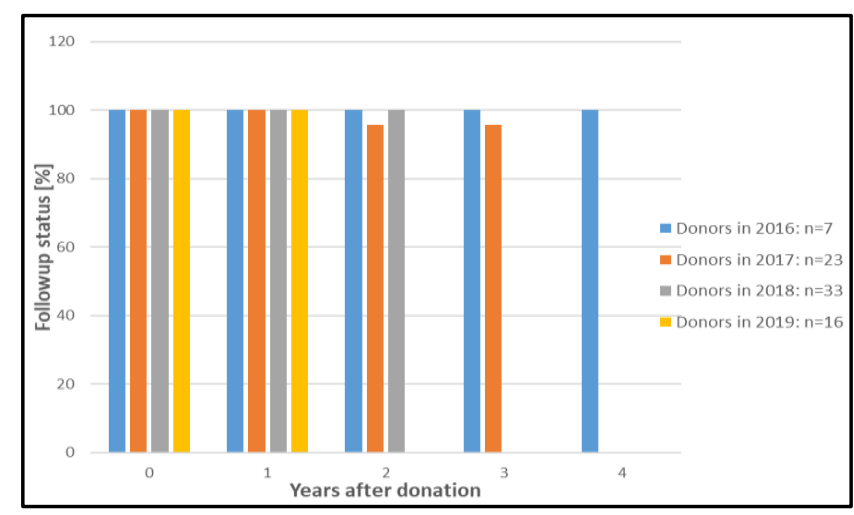

Figure: Percentage of follow-up of donors.

5. For this reason, there are no donors from 2019 to have reportedthe hypertension, since they are followed up only one year after the donation (table-IV).

Furthermore, it is observed that the number of donors developing the hypertension is increasing with

Table-II: Group wise systolic and diastolic blood pressure of donors in 2016 during follow up.

\begin{tabular}{|c|c|c|c|c|c|}
\hline & \multirow[t]{2}{*}{ Variable } & \multicolumn{2}{|c|}{$\begin{array}{c}\text { Normotensive } \\
\text { Donors }\end{array}$} & \multicolumn{2}{|c|}{$\begin{array}{l}\text { Hypertensive } \\
\text { Donors }\end{array}$} \\
\hline & & $\mathbf{n}$ & Mean \pm SD & $\mathbf{n}$ & Mean \pm SD \\
\hline \multirow{2}{*}{$\begin{array}{l}\text { Dona- } \\
\text { tion } \\
\text { time }\end{array}$} & Systole & \multirow[b]{2}{*}{3} & $116.67 \pm 5.77$ & \multirow[b]{2}{*}{4} & $117.5 \pm 5$ \\
\hline & Diastole & & $76.67 \pm 5.77$ & & $77.5 \pm 5$ \\
\hline \multirow{2}{*}{ Year 1} & Systole & \multirow{2}{*}{3} & $113.33 \pm 5.77$ & \multirow{2}{*}{4} & $120 \pm 0$ \\
\hline & Diastole & & $76.67 \pm 5.77$ & & $80 \pm 0$ \\
\hline \multirow{2}{*}{ Year 2} & Systole & \multirow{2}{*}{3} & $113.33 \pm 5.77$ & \multirow{2}{*}{4} & $137.5 \pm 15$ \\
\hline & Diastole & & $76.67 \pm 5.77$ & & $87.5 \pm 5$ \\
\hline \multirow{2}{*}{ Year 3} & Systole & \multirow{2}{*}{3} & $120 \pm 10$ & \multirow{2}{*}{4} & $130 \pm 0$ \\
\hline & Diastole & & $75 \pm 5$ & & $90 \pm 0$ \\
\hline \multirow{2}{*}{ Year 4} & Systole & \multirow{2}{*}{3} & $113.33 \pm 11.55$ & \multirow{2}{*}{4} & $133.5 \pm 16.01$ \\
\hline & Diastole & & $71.67 \pm 2.89$ & & $86.25 \pm 7.5$ \\
\hline
\end{tabular}

Table-III: Group wise systolic and diastolic blood pressure of donors in 2017 during follow up.

\begin{tabular}{|c|c|c|c|c|c|}
\hline & \multirow[t]{2}{*}{ Variable } & \multicolumn{2}{|c|}{$\begin{array}{l}\text { Normotensive } \\
\text { Donors }\end{array}$} & \multicolumn{2}{|c|}{$\begin{array}{l}\text { Hypertensive } \\
\text { Donors }\end{array}$} \\
\hline & & $\mathbf{n}$ & Mean \pm SD & $\mathbf{n}$ & Mean \pm SD \\
\hline \multirow{2}{*}{$\begin{array}{l}\text { Dona- } \\
\text { tion } \\
\text { time }\end{array}$} & Systole & \multirow[b]{2}{*}{15} & $116 \pm 5.07$ & \multirow[b]{2}{*}{8} & $117.5 \pm 4.63$ \\
\hline & Diastole & & $74.67 \pm 6.4$ & & $75 \pm 7.56$ \\
\hline \multirow[t]{2}{*}{ Year 1} & Systole & \multirow[t]{2}{*}{15} & $\begin{array}{c}112.67 \pm \\
7.99 \\
\end{array}$ & \multirow[t]{2}{*}{8} & $\begin{array}{c}127.5 \pm \\
28.16\end{array}$ \\
\hline & Diastole & & $71.33 \pm 7.43$ & & $76.25 \pm 9.16$ \\
\hline \multirow[t]{2}{*}{ Year 2} & Systole & \multirow[t]{2}{*}{14} & $\begin{array}{c}113.57 \pm \\
4.97\end{array}$ & \multirow[t]{2}{*}{8} & $\begin{array}{c}126.25 \pm \\
20.66\end{array}$ \\
\hline & Diastole & & $72.86 \pm 4.26$ & & $85 \pm 13.09$ \\
\hline \multirow{2}{*}{ Year 3} & Systole & \multirow{2}{*}{14} & $\begin{array}{c}120.71 \pm \\
6.16\end{array}$ & \multirow{2}{*}{8} & $\begin{array}{c}128.12 \pm \\
14.62 \\
\end{array}$ \\
\hline & Diastole & & $\begin{array}{c}71.29 \pm \\
18.85 \\
\end{array}$ & & $88.75 \pm 8.76$ \\
\hline
\end{tabular}

time as shown in figure. For a four year follow up of the donors from 2016, 57.1\% of the donors developed hypertension. For a three year follow up of the donors from 2017, 34.8\% of donors developed hypertension whereas $30.3 \%$ of donors from 2018 developed hypertension during a two year follow up. This clearly establishes the increased risk of hypertension with time.

Table-IV: Group wise systolic and diastolic blood pressure of donors in 2018 during follow up.

\begin{tabular}{|c|c|c|c|c|c|}
\hline & \multirow{2}{*}{ Variable } & \multicolumn{2}{|c|}{$\begin{array}{c}\text { Normotensive } \\
\text { Donors }\end{array}$} & \multicolumn{2}{|c|}{$\begin{array}{c}\text { Hypertensive } \\
\text { Donors }\end{array}$} \\
\hline & & $\mathbf{n}$ & Mean \pm SD & $\mathbf{n}$ & $\begin{array}{l}\text { Mean } \pm \\
\text { SD }\end{array}$ \\
\hline \multirow{2}{*}{$\begin{array}{l}\text { Dona- } \\
\text { tion } \\
\text { time }\end{array}$} & Systole & \multirow[t]{2}{*}{23} & $\begin{array}{c}117.39 \pm \\
4.49\end{array}$ & \multirow[t]{2}{*}{10} & $118 \pm 4.22$ \\
\hline & Diastole & & $77.39 \pm 4.49$ & & $77 \pm 4.83$ \\
\hline \multirow[t]{2}{*}{ Year 1} & Systole & \multirow[t]{2}{*}{23} & $\begin{array}{c}114.35 \pm \\
6.62\end{array}$ & \multirow[t]{2}{*}{10} & $124 \pm 14.3$ \\
\hline & Diastole & & $73.48 \pm 4.87$ & & $87 \pm 14.94$ \\
\hline \multirow[t]{2}{*}{ Year 2} & Systole & \multirow[t]{2}{*}{23} & $\begin{array}{c}116.96 \pm \\
5.59\end{array}$ & \multirow[t]{2}{*}{10} & $135 \pm 7.07$ \\
\hline & Diastole & & $75.22 \pm 5.11$ & & $88 \pm 7.14$ \\
\hline
\end{tabular}

Table-V: Group wise systolic and diastolic blood pressure of donors in 2019 during follow up.

\begin{tabular}{|c|c|c|c|c|c|}
\hline & \multirow{2}{*}{ Variable } & \multicolumn{2}{|c|}{$\begin{array}{c}\text { Normotensive } \\
\text { Donors }\end{array}$} & \multicolumn{2}{|c|}{$\begin{array}{l}\text { Hypertensive } \\
\text { Donors }\end{array}$} \\
\hline & & $\mathbf{n}$ & Mean \pm SD & $\mathbf{n}$ & $\begin{array}{c}\text { Mean } \pm \\
\text { SD }\end{array}$ \\
\hline \multirow{2}{*}{$\begin{array}{l}\text { Dona- } \\
\text { tion } \\
\text { time }\end{array}$} & Systole & \multirow[b]{2}{*}{16} & $120 \pm 6.32$ & \multirow[b]{2}{*}{0} & - \\
\hline & Diastole & & $78.75 \pm 3.42$ & & - \\
\hline \multirow{2}{*}{ Year 1} & systole & \multirow{2}{*}{16} & $113.12 \pm 4.79$ & \multirow{2}{*}{0} & - \\
\hline & diastole & & $74.38 \pm 5.12$ & & - \\
\hline
\end{tabular}

\section{DISCUSSION}

First successful kidney transplant was done in 1954 when kidney was donated by identical twin of the donor ${ }^{1}$. Sincethen, the number of kidney transplant are on a rising verge. Effects on donor's health in long term weren't determined initially but surgery kept on going considering a good faith belief, assuming no damage to donor. In 1980s some experimental reports emerged that nephrectomy is associated with hyper filtration injury which ultimately leads to hypertension, proteinuria and glomerulosclerosis ${ }^{2}$. So rates of living donor transplant waned. Though this data was not derived from humans. Kidney transplant kept on being performed and for past few years, it's incidence has increased significantly and it surpassed cadaveric donors $^{3}$. People involved in transplant acknowledge contribution if living donors and many safeguards are 
in place for their protection. But no concrete well designed prospective studies are conducted to proof $\mathrm{it}^{4,5}$.

In early studies, live donor transplant nephrectomy was not considered a risk factor for development of hypertension ${ }^{6}$. When matched to general population no significant difference was found in occurrence of hypertension and hence micro albuminuria ${ }^{7,8}$. These were small population studies with retrospective design, a small cohort, use of general population as control group, poor statistical designs and lost to follow up. In recent past some studies found contrary results with an increased risk of hypertension in donors7,8.

In a prospective Swiss cohort, conducted over 18 years shows that it triplicates risk of hypertension in kidney donors in short term and leads to microalbuminuria too'. In a study conducted by Ramesh et al showed that 51 donors, who were consented, predonation blood pressure in normotensive persons was not correlated with post-donation cardiovascular and kidney functions ${ }^{10}$.

In another study conducted by Kiberd et al in USA, the study showed that $1-5 \%$ of patients has chances to develop ESRD as a result of kidney donation ${ }^{11}$. The additional peril of ESRD caused a loss of almost 0.126-0.344 remaining life years. Obesity and smoking reduced life expectancy and amplified overall life spanhazards of ESRD.

In a meta-analysis of multiple studies conducted by Ommen et al, it was shown that living donors, particularly living related donors, are at enlarged risk for being hypertensive or developing kidney disease. It further argues that absence of proof is not proof of absence after conducting a thorough analysis across many trials ${ }^{12}$.

Systematic collection of data of all donors allows to look for long term outcome and also gives opportunity for timely intervention. It will also allow to improvise policy for long term follow up.

In a meta-analysis Boudville et al concluded that after nephrectomy $5 \mathrm{~mm} \mathrm{Hg}$ average blood pressure rise occurs but risk of hypertension cannot be evaluated because of heterogeneity of data and weakness of study ${ }^{13}$. In the recent study conducted in Israel by Grupper et al, it was concluded that donors are more likely to developclinical picture of metabolic syndrome besidesdrop in GFR and greater than before urine albumin excretion ${ }^{14}$.

Strengths of our study are its extensive retrospective design, large donor population, extensive follow up and complete data set hence strong hypertensive outcome classification. Details of smoking status and hypertension family history were also accessible for all donors. Most of the donors were available for follow up and those not making were contacted via telemedicine.

Among weakness of our study were retrospective design, inclusion of use of antihypertensive therapy in definition of hypertension as it leads to increased hypertensive population and weak system of telemedicine hence resulting in some degree of loss to follow up.

In summary our study supports nephrectomy a risk factor for hypertension but a life long follow up of donor and continuous observing of blood pressure and urinary albumin excretion are recommended to avoid any unfavorable outcome. Those who are diagnosed with hypertension should be placed on ACE Inhibitors or Angiotensin receptor antagonists. All transplant centers should have a centralized data registry with lifelong follow up of donor as well.

\section{CONCLUSION}

The patients donating kidney are at increased risk of developing hypertension in subsequent years post donation. Those patients who eventually develop hypertension are already at increased risk of developing hypertension post donation. These hypertensive donors are susceptible to worsening hypertension over period of 4 years and need medical attention. Kidney donors should be regularly followed up as a part of hospital health care policy.

\section{CONFLICT OF INTEREST}

This study has no conflict of interest to be declared by any author.

\section{REFERENCES}

1. Ommen ES, Winston JA, Murphy B. Medical risks in living kidney donors: absence of proof is not proof of absence. Clin J Am Soc Nephrol 2006; 1(1): 885-95.

2. Grupper A, Angel Y, Baruch Y, Schwartz IF, Schwartz D, Nakache R, et al. Long term metabolic and renal outcomes of kidney donors compared to controls with excellent kidney function. BMC Nephrology 2019; 14(4): 20-24.

3. Lentine KL, Lam NN, Axelrod D, Schnitzler MA, Garg AX, Xiao $\mathrm{H}$, et al. Perioperative complications after living kidney donation: a national study. Am J Transplant 2016; 16(6): 1848-57.

4. Thiel GT, Nolte C, Tsinalis D. Prospective swiss cohort study of living-kidney donors: study protocol. Br Med J Open 2011; 1(1): e000202.

5. Sanchez OA, Ferrara LK, Rein S, Berglund D, Matas AJ, Ibrahim $\mathrm{HN}$, et al. Hypertension after kidney donation: incidence, predictors and correlates. Am J Transplant 2018; 18(10): 2534-43.

6. Morgan BR, Ibrahim HN. Long-term outcomes of kidney donors. Curr Opin Nephrol Hypertens 2011; 20(6): 605-09. 
7. Flechner SM, Thomas AG, Ronin M, Veale JL, Leeser DB, Kaur $S$, et al. The first 9 years of kidney paired donation through the national kidney registry: characteristics of donors and recipients compared to national live donor transplant registries. Am J Transplant 2018; 18(11): 2730-38.

8. Housawi AA, Young A, Boudville N, Thiessen-Philbrook H, Muirhead N, Rehman F, et al. Transplant professionals vary in the long-term medical risks they communicate to potential living kidney donors: an international survey. Nephrol Dial Transplant 2007; 22(10): 3040-45.

9. Ramesh Prasad GV, Lipszyc D, Sarker S, Huang M, Nah MM, Rapi L, et al. Twenty four-hour ambulatory blood pressure profiles 12 months' post living kidney donation. Transpl Int 2010; 23(8): 771-76.

10. Thiel GT, Nolte C, Tsinalis D. Investigating kidney donation as a risk factor for hypertension and microalbuminuria: findings from the Swiss prospective follow-up of living kidney donors. Br Med J Open 2016; 6(3): e010869.

11. Kiberd BA, Tennankore KK. Lifetime risks of kidney donation: a medical decision analysis. Br Med J Open 2017; 7(8): e016490.

12. Ommen ES, Winston JA, Murphy B. Medical risks in living kidney donors: absence of proof is not proof of absence. Clin J Am Soc Nephrol 2006; 1(5): 885-95.

13. Boudville N, Prasad GV, Knoll G, Muirhead N, Thiessen-Phil- brook H, Yang RC, et al. Meta-analysis: risk for hypertension in living kidney donors. Ann Intern Med 2006; 145(3): 185-96.

14. Grupper A, Angel Y, Baruch Y, Schwartz IF, Schwartz D, Nakache R, et al. Long term metabolic and renal outcomes of kidney donors compared to controls with excellent kidney function. BMC Nephrology 2019; 14(4): 20.

15. Parikh NI, Pencina MJ, Wang TJ, Benjamin EJ, Lanier KJ. A risk score for predicting near-term incidence of hypertension: The Framingham Heart Study. Ann Intern Med 2008; 148(2): 102-10.

16. Levey AS, Cattran D, Friedman A, Miller WG, Sedor J, Tuttle K, et al. Proteinuria as a surrogate outcome in CKD: report of a scientific workshop sponsored by The National Kidney Foundation and the US Food and Drug Administration. Am J Kidney Dis 2009; 54(2): 205-26.

17. Lentine KL, Segev DL. Understanding and communicating medical risks for living kidney donors: A matter of perspective. J Am Soc Nephrol 2017; 28(3): 12-24.

18. Lam N, Huang A, Feldman LS, Gill JS, Karpinski M, Kim J, et al. Donor nephrectomy outcome research (DONOR) network: acute dialysis risk in living kidney donors. Nephrol Dial Transplant 2012; 27(4): 3291-95.

19. Massie AB, Muzzale AD, Luo X, Chow EKH, Locke JE, Nguyen $\mathrm{AQ}$, et al. Quantifying postdonation risk of ESRD in living kidney donors. J Am Soc Nephrol 2017; 28(6): 2479-755. 